Resectron

\title{
Mice deficient in PAPP-A show resistance to the development of diabetic nephropathy
}

\author{
Jessica R Mader, Zachary T Resch, Gary R McLean ${ }^{2}$, Jakob H Mikkelsen $^{3}$, Claus Oxvig $^{3}$, \\ Ronald J Marler ${ }^{1}$ and Cheryl A Conover
}

Endocrine Research Unit, Division of Endocrinology, Mayo Clinic, 200 First Street SW, 5-194 Joseph, Rochester, Minnesota 55905, USA

${ }^{1}$ Department of Comparative Medicine, Mayo Clinic, Collaborative Research Building, 13400 E Shea Boulevard, Scottsdale, Arizona 85259, USA

${ }^{2}$ Cellular and Molecular Immunology Research Centre, London Metropolitan University, London, UK

${ }^{3}$ Department of Molecular Biology and Genetics, Aarhus University, Gustav Wieds Vej 10C, DK-8000 Aarhus C, Denmark

Correspondence should be addressed to C A Conover Email conover.cheryl@mayo.edu

\begin{abstract}
We investigated pregnancy-associated plasma protein-A (PAPP-A) in diabetic nephropathy. Normal human kidney showed specific staining for PAPP-A in glomeruli, and this staining was markedly increased in diabetic kidney. To assess the possible contribution of PAPP-A in the development of diabetic nephropathy, we induced diabetes with streptozotocin in 14-month-old WT and Papp-A knockout (KO) mice. Renal histopathology was evaluated after 4 months of stable hyperglycemia. Kidneys from diabetic WT mice showed multiple abnormalities including thickening of Bowman's capsule (100\% of mice), increased glomerular size ( $80 \%$ of mice), tubule dilation ( $80 \%$ of mice), and mononuclear cell infiltration ( $90 \%$ of mice). Kidneys of age-matched non-diabetic WT mice had similar evidence of tubule dilation and mononuclear cell infiltration to those of diabetic WT mice, indicating that these changes were predominantly age-related. However, thickened Bowman's capsule and increased glomerular size appeared specific for the experimental diabetes. Kidneys from diabetic Papp-A KO mice had significantly reduced or no evidence of changes in Bowman's capsule thickening and glomerular size. There was also a shift to larger mesangial area and increased macrophage staining in diabetic WT mice compared with Papp-A KO mice. In summary, elevated PAPP-A expression in glomeruli is associated with diabetic nephropathy in humans and absence of PAPP-A is associated with resistance to the development of indicators of diabetic nephropathy in mice. These data suggest PAPP-A as a potential therapeutic target for diabetic nephropathy.
\end{abstract}

\section{Key Words}

- pregnancy-associated plasma protein-A

- kidney

diabetes

- Bowman's capsule
Journal of Endocrinology (2013) 219, 51-58

\section{Introduction}

Pregnancy-associated plasma protein-A (PAPP-A) was initially identified as one of four proteins found at high concentrations in the circulation of pregnant women, hence its name (Lin et al. 1974). Subsequently, PAPP-A was discovered to be a novel zinc metalloprotease expressed by a variety of cell types and tissues unrelated to pregnancy http://joe.endocrinology-journals.org DOI: 10.1530/JOE-13-0167
(C) 2013 Society for Endocrinology Printed in Great Britain
Published by Bioscientifica Ltd 
(Lawrence et al. 1999, Conover et al. 2006, Qin et al. 2006). In vitro and in vivo studies indicate that PAPP-A functions to enhance the growth-stimulating actions of local insulin-like growth factors (IGFs) through cleavage of inhibitory IGF binding proteins (reviewed in Conover 2012). Although a benefit in many tissues in early life, PAPP-A (and IGFs) can have detrimental effects in later life with promotion of aging and age-related disease (Conover et al. 2004, Conover 2010). Indeed, Papp-A knockout (KO) mice live $30-40 \%$ longer than their WT littermates with reduced incidence and severity of degenerative diseases of age, such as nephropathy (Conover et al. 2010). These histopathological data suggesting a role for PAPP-A in the aging kidney, the renal expression of multiple components of the IGF1 system (Vasyleva \& Ferry 2007), and the reported effects of IGF1 in promoting matrix production and proliferation of kidney cells (Horney et al. 1998, Lupia et al. 1999) prompted us to investigate the role of PAPP-A in the development of diabetic nephropathy, the leading cause of end-stage renal disease worldwide (US Renal Data System Annual Report 2008). There were two aims of this study: i) to assess PAPP-A expression in kidneys from normal and diabetic subjects by immunohistochemistry and ii) to determine the effect of Papp-A gene deletion on the development of nephropathy in an experimentally induced mouse model of type 2 diabetes. The latter was of particular interest based on a study by Swindell et al. (2010) looking at differential gene expression in WT vs Papp-A KO mice that highlighted the kidney as a tissue in which moderated IGF signaling could have favorable effects.

\section{Materials and methods}

\section{PAPP-A immunohistochemistry human kidney}

Fresh-frozen normal and diabetic kidney sections were obtained from AMSBIO (Abingdon, UK). Sections were fixed in 100\% methanol, rehydrated in PBS, and probed for PAPP-A protein expression using recombinant anti-PAPP-A MAB ( J H Mikkelsen \& C Oxvig, unpublished observations) and detected with a FITC-labeled secondary antibody (Jackson ImmunoResearch Laboratories, West Grove, PA, USA). PAPP-A staining was visualized using a LSM 510 Confocal Laser Scanning Microscopes (Carl Zeiss MicroImaging, Oberkochen, Germany) at $40 \times$ magnification with DAPI used as a nuclear counterstain. Mouse IgG2 $\alpha$ was used as an isotype control.

\section{Mice}

Adapting the protocol of Wu et al. (2010), 14-month-old female PAPP-A KO and WT mice received i.p. injections of streptozotocin $(50 \mu \mathrm{g} / \mathrm{g}$ per injection) freshly dissolved in $137 \mathrm{mM}$ Na citrate, $\mathrm{pH} 4.5$, every 2-3 days for a total of five to seven injections in order to induce stable hyperglycemia. Mice were placed in clean cages and fasted for $4 \mathrm{~h}$ prior to each injection. Body weight and blood glucose levels were measured prior to the initial streptozotocin injection and weekly for 4 months afterwards, in each instance after a 4-h fast. Mice were considered diabetic when their blood glucose level was sustained at $\geq 250 \mathrm{mg} / \mathrm{dl}$. There was $<10 \%$ mortality, and dead or killed animals were excluded from further study. Mice were not treated with insulin at any time during the study. After 4 months of stable diabetes, body and kidney weights were recorded, blood was collected, and right and left kidneys were prepared for fixation. All procedures were approved by Mayo Clinic's Institutional Animal Care and Use Committee.

\section{Renal histology}

The right kidney was cut in cross section and the left kidney was cut longitudinally, rinsed in PBS, and fixed overnight in Bouin's solution. Fixed tissues were flushed for $10 \mathrm{~min}$ with tap water and stored at $4{ }^{\circ} \mathrm{C}$ in PBS until shipping to the Animal Histology Core at Mayo Clinic (Scottsdale, AZ, USA) for sectioning and staining with hematoxylin-eosin. Kidney sections were qualitatively assessed by an American College of Veterinary Pathologists board-certified veterinary pathologist (R J M). A blinded histopathology report was based on standard descriptions and terminology (see legend to Table 1), and given one of four subjective grades of minimal, mild, moderate, and marked. Sections of kidney were also stained with periodic acid-Schiff (PAS) to measure mesangial area within each glomerulus using Adobe PhotoShop Software (Adobe Systems, Inc.). At least 300 glomeruli from three mice were assessed per group.

\section{Immunohistochemistry}

De-paraffinized sections of mouse kidney were stained for macrophages using F4/80 as primary antibody. Slides were rinsed with Tris-buffered saline and $0.01 \%$ Tween 20 for $3 \mathrm{~min}$, treated with peroxidase blocking reagent (Dako, Carpinteria, CA, USA) for 5 min, rinsed with wash buffer (Dako), and treated with Rodent Block M (Biocare Medical, Concord, CA, USA) for $30 \mathrm{~min}$. Slides were then incubated with primary antibody (F4/80 CI:A3-1, rat monoclonal, AbD

Published by Bioscientifica Ltd. 
Table 1 Diabetic kidney histology. Numbers represent the percentage of mice with the indicated observations, assessed in a blinded fashion as described in the Materials and methods and Results sections. Fisher's exact test was used to compare proportions. Mononuclear cell infiltration: aggregates of primarily lymphocytes that were prominently noted around arterioles in the cortex, but also seen around larger vessels in the pelvis. The blood vessels within the aggregates of mononuclear cells were often prominent. Dilation of cortex/medulla tubules increased: dilated tubules that often contained eosinophilic (proteinaceous) filtrate. Cytoplasmic alteration of cortex tubules: characterized by small groups of tubules with subtle cytoplasmic granularity. The tubules stained lightly eosinophilic to lightly basophilic. Thickened Bowman's membrane: noticeable thickening of the membrane in several glomerular tufts. Increased glomerular size: the change was characterized by an increase in mesangial size that was often associated with an increase in cellularity, mesangial matrix, and/or prominent juxtaglomerular area. Other: amyloid: small aggregates of homogeneous, eosinophilic material within an area of mononuclear cell infiltrate. Presumptive amyloid. Metaplasia: small bone spicule in left kidney. None of the changes in any of the tissue section were graded greater than mild and most were minimal in severity

\begin{tabular}{|c|c|c|c|}
\hline & \multicolumn{2}{|c|}{ Diabetic } & \multirow{2}{*}{$\begin{array}{c}\text { Non-diabetic } \\
\text { WT }(n=12)\end{array}$} \\
\hline & WT $(n=10)$ & Papp-A KO $(n=13)$ & \\
\hline Mononuclear cell infiltration (\%) & 90 & 77 & 100 \\
\hline Tubule dilation (\%) & 80 & $0^{\mathrm{a}}$ & 75 \\
\hline Tubule cytoplasmic changes (\%) & 10 & 0 & 8 \\
\hline Thickened Bowman's (\%) & 100 & $<1^{\mathrm{a}}$ & $7^{b}$ \\
\hline Increased glomerular size (\%) & 80 & 23 & 17 \\
\hline Two or more abnormalities (\%) & 100 & 23 & 58 \\
\hline Other abnormalities (\%) & 40 & 0 & 58 \\
\hline
\end{tabular}

asignificant difference between 18-month-old diabetic Papp-A KO and diabetic WT mice.

${ }^{b}$ Significant difference between 18-month-old non-diabetic and diabetic WT mice.

Serotec, Raleigh, NC, USA) for $60 \mathrm{~min}$ at room temperature at a concentration of 1:200 (diluted in Background Reducing Diluent (Dako)), followed by incubation with secondary antibody (Rat on Mouse Probe, Biocare, prediluted) for $15 \mathrm{~min}$ at room temperature. Slides were rinsed three times in wash buffer, incubated with tertiary reagent (Rat on Mouse HRP, BioCARE, Tempe, AZ, USA) for 15 min at room temperature, rinsed in wash buffer, and then stained for visualization with diaminobenzidine (Biocare) for 5 min. Counterstaining with hematoxylin, followed by dehydration in increasing concentrations of ethyl alcohol and xylene, was performed prior to cover slipping.

\section{Blood chemistry}

Blood urea nitrogen (BUN) measurements were performed using a Urea Nitrogen assay kit purchased from Pointe Scientific, Inc. (Canton, MI, USA). Serum IGF1 was measured using a mouse IGF1 ELISA kit generously provided by ImmunoDiagnostic Systems (Fountain Hills, AZ, USA).

\section{Statistical analysis}

Fisher's exact test was used to compare proportions of mice between groups. Two-tailed ANOVA and Tukey's tests were used for multiple comparisons of group means. $P<0.05$ was considered statistically significant.

\section{Results}

\section{PAPP-A expression in human kidney}

PAPP-A immunohistochemistry of sections from a normal human kidney and a kidney from a patient with diabetic nephropathy is presented in Fig. 1. In normal kidney, there was specific staining for PAPP-A within and around the glomerulus, the structural unit responsible for filtration of the plasma that is eventually processed into urine. In comparison, diabetic kidney had manifestly more intense staining in the glomerulus as well as in association with the thickened Bowman's capsule, the latter being a prominent feature of diabetic nephropathy.

\section{General characteristics of diabetic and non-diabetic mice}

There was a significant difference in body weight between WT and Papp-A KO mice, as reported previously (Conover et al. 2004), but there was no significant difference in body weight in the diabetic mice (WT and Papp-A KO) when compared with their respective non-diabetic controls

Published by Bioscientifica Ltd 


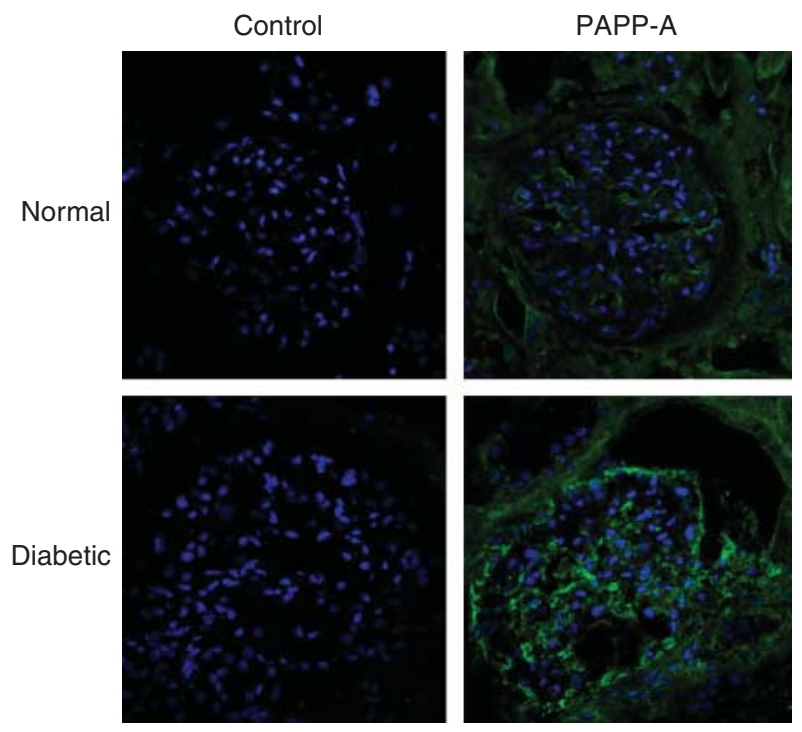

Figure 1

PAPP-A expression in human kidney. Sections of human kidney from a normal healthy subject and from a patient with diabetic nephropathy stained with primary antibody to PAPP-A or with isotype control, $\operatorname{lgG} 2 \alpha$. Green, PAPP-A; blue, nuclei.

(Table 2). There was a significant difference in the kidney weight/body weight ratio between diabetic WT and Papp-A KO mice. However, this was not caused by the diabetic phenotype, as a similar difference was seen in non-diabetic mice. There was no significant difference in the harvest blood glucose level between WT and Papp- $A$ KO mice, although levels were significantly elevated in the diabetic mice compared with non-diabetic mice as expected from this model. There was no significant difference in BUN levels between diabetic WT and Papp- $A$ KO mice, although they were slightly elevated in diabetic compared with nondiabetic mice. These characteristics suggest changes in kidney function with 4 months of hyperglycemia, although urine was not collected for measurement of creatinine or albumin. Furthermore, serum IGF1 levels were not significantly different between diabetic WT and Papp-A KO mice or between diabetic and non-diabetic WT mice, confirming previous characterization of Papp-A KO mice as a model of autocrine/paracrine vs endocrine regulation of IGF action (Conover et al. 2004).

\section{Renal histology}

Diabetes induced by streptozotocin in aged mice results in glomerular, tubulointerstitial, and vascular kidney lesions with many features of human diabetic nephropathy (Fioretto \& Mauer 2007, Wu et al. 2010). These are morphologically characterized by thickening of the Bowman's capsule, glomerular hypertrophy with expansion of the extracellular matrix surrounding mesangial cells, and thickening of the basement membrane underlying proximal tubular epithelial cells.

WT diabetic mice developed thickening of Bowman's capsule, tubular changes, and interstitial infiltrates (Fig. 2 and Table 1). The glomeruli were enlarged in $80 \%$ and the basement membrane of Bowman's capsules was thickened in $100 \%$ of WT diabetic kidneys. Tubular dilation was noted in $80 \%$ of the kidneys and mononuclear infiltrates noted in $90 \%$. Forty percent of the kidneys had additional abnormalities and all WT diabetic kidneys had two or more abnormalities. In contrast, diabetic Papp-A KO kidneys showed little or no changes in glomerular size, Bowman's capsule, and tubular dilation. However mononuclear cell infiltration was not different between diabetic WT and Papp-A KO mice. To distinguish age-related vs hyperglycemia-induced effects on renal histology, we also examined 12 age-matched non-diabetic WT kidneys and found little or no thickening of Bowman's membrane or increase in glomerular size, although mononuclear cell

Table 2 General characteristics of diabetic and non-diabetic WT and Papp-A KO mice. Data for 18-month-old diabetic and non-diabetic mice are presented as mean \pm s.E.M. with the number of mice for each group in parentheses. Analysis was by ANOVA and Tukey's tests

\begin{tabular}{|c|c|c|c|c|}
\hline \multirow[b]{2}{*}{ Measurements } & \multicolumn{2}{|c|}{ Diabetic } & \multicolumn{2}{|c|}{ Non-diabetic } \\
\hline & WT $(n=10)$ & Papp-A KO $(n=13)$ & WT $(n=8)$ & Papp-A KO $(n=6)$ \\
\hline Body weight (g) & $34.2 \pm 2.05$ & $22.0 \pm 1.19 *$ & $37.0 \pm 3.17$ & $24.4 \pm 3.71 *$ \\
\hline Kidney:body weight ratio $(\mathrm{mg} / \mathrm{g})$ & $10.0 \pm 0.55$ & $11.6 \pm 0.13$ & $10.5 \pm 0.68$ & $12.1 \pm 1.68^{*}$ \\
\hline Blood glucose (mg/dl) & $277 \pm 44$ & $310 \pm 28$ & $130 \pm 6.0^{\dagger}$ & $143 \pm 4.5^{\dagger}$ \\
\hline Blood urea nitrogen $(\mathrm{mg} / \mathrm{dl})$ & $22 \pm 2.6$ & $29 \pm 1.5$ & $19 \pm 2.0$ & $22(n=1)$ \\
\hline Serum IGF1 (ng/ml) & $500 \pm 40$ & $475 \pm 59$ & $538 \pm 66$ & ND \\
\hline
\end{tabular}

${ }^{*} P<0.05$ Papp-A KO vs WT and ${ }^{\dagger} P<0.05$ diabetic vs non-diabetic. ND, no data.

http://joe.endocrinology-journals.org DOI: 10.1530/JOE-13-0167
(C) 2013 Society for Endocrinology Printed in Great Britain
Published by Bioscientifica Ltd 


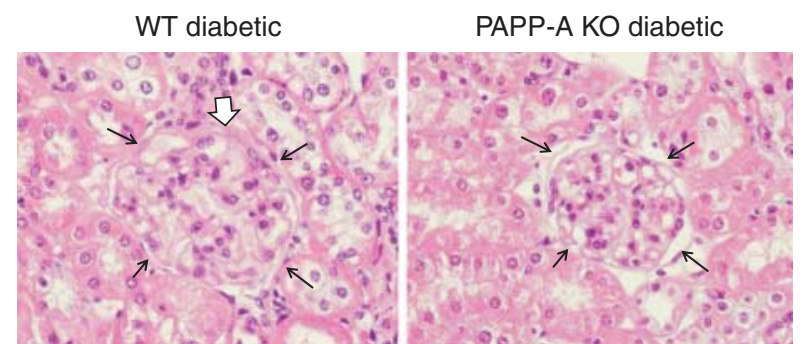

Figure 2

Renal histology of diabetic WT and Papp-A KO mice. Representative H\&E staining of kidney sections. Thin black arrows delineate a glomerulus. Broad white arrow indicates thickened Bowman's capsule.

infiltration and tubular dilation was similar to what was seen in diabetic WT kidneys (Table 1).

Expansion of mesangial matrix that is strongly PASpositive is a hallmark pathological feature of diabetic nephropathy (Steffes et al. 1989). Mesangial area was quantitated in PAS-stained diabetic kidneys and there was a significant shift to larger area in WT compared with Papp-A KO mice (Fig. 3). Mean mesangial area in WT and Papp-A KO was $3587 \pm 79$ and $2518 \pm 132 \mu \mathrm{m}^{2}$ respectively $(P=0.002)$. This was not just due to the overall larger body size of the WT mice because mesangial area in nondiabetic WT kidney was similar to what was seen in diabetic Papp-A KO kidney (data not shown).

\section{Macrophage immunohistochemistry}

Immunostaining for $\mathrm{F} 4 / 80$, a classical macrophagerestricted surface glycoprotein, is specific for macrophages. Macrophages were prominent in kidneys of diabetic WT mice and appeared to be diminished in kidneys of diabetic Papp- $A$ KO mice (Fig. 4). Intensity of staining around the glomeruli was graded as 1, 2, or 3 (3 being the highest intensity). Non-diabetic control kidneys were grade 1 . Assessment of WT diabetic kidneys $(n=9)$ classified $22 \%$ as grade $1,22 \%$ as grade 2 , and $56 \%$ as grade 3 . In comparison, assessment of Papp- $A$ KO kidneys ( $n=13$ ) classified $62 \%$ as grade $1,38 \%$ as grade 2 , and none as grade 3 .

\section{Discussion}

Diabetic nephropathy is the leading cause of end-stage renal disease world-wide (US Renal Data System Annual Data Report 2008). Therefore, there is tremendous interest in identifying factors regulating the development of diabetic nephropathy with the intent to prevent or delay the associated morbidity and mortality. Based on previous findings that suggest a role for PAPP-A in age-related nephropathy (Conover et al. 2010), we investigated the role of PAPP-A in diabetic nephropathy. The two major and novel findings of this study were as follows: i) PAPP-A expression is markedly elevated in glomeruli of human diabetic kidneys and ii) mice deficient in PAPP-A are resistant to the development of diabetic nephropathy.

\section{Human diabetic nephropathy}

It is important for the study of PAPP-A in diabetic nephropathy to ascertain where PAPP-A is expressed in the kidney and if there is site-specific regulation in diabetes. Although mouse kidney has been reported to have high levels of PAPP-A mRNA (Hourvitz et al. 2002, Conover et al. 2004), these studies were performed in whole kidney and there were/are no antibodies available that recognize murine PAPP-A. Thus, our data are the first, to our knowledge, to demonstrate specific immunolocalization of PAPP-A to glomeruli. Furthermore, the kidney of a patient with confirmed diabetic nephropathy had markedly elevated PAPP-A associated with the glomerulus as well as the surrounding Bowman's capsule. This was of particular interest as the glomerulus is a major target of renal injury, especially in diabetes (Schlondorff 2008). It is not clear from immunohistochemistry which cells produce PAPP-A because it is a secreted protein that can associate with neighboring cells as well as the cells of origin (Conover et al. 2007). In this way, PAPP-A can act as an autocrine/paracrine regulator of IGF action. A clinical study indicated the prognostic value of circulating PAPP-A

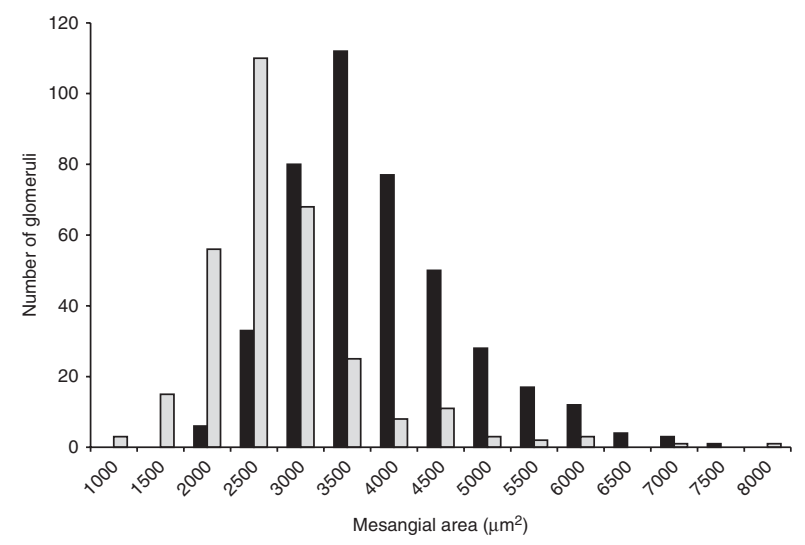

Figure 3

Mesangial area. Kidney sections from diabetic WT (black bars) and Papp-A KO (grey bars) mice were stained with PAS and mesangial area measured as described in the Materials and methods section.

Published by Bioscientifica Ltd. 


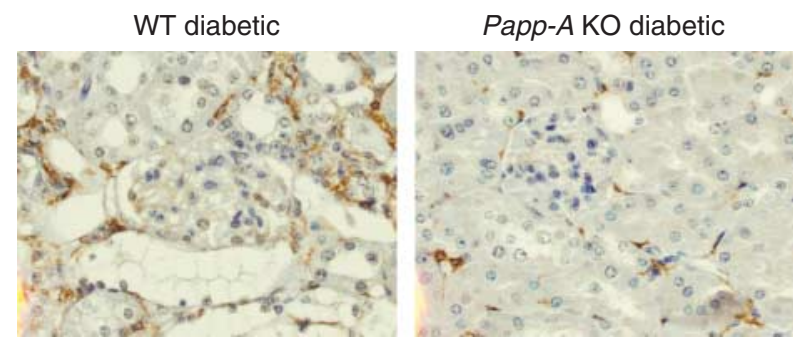

Figure 4

Macrophage immunohistochemistry of diabetic WT and Papp-A KO kidney. Macrophage staining for F4/80 (red brown) of kidney sections from WT diabetic (grade 3) and Papp-A KO diabetic (grade 1) mice.

with respect to increased all-cause mortality in type I diabetic patients with nephropathy (Astrup et al. 2007). However, it is not known whether this increase in circulating PAPP-A reflected changes in the kidney.

\section{Mouse diabetic nephropathy}

In order to investigate the physiological and pathophysiological role of PAPP-A in the kidney, we used WT and Papp-A KO mice and induced stable hyperglycemia in these animals with a regimen of low-dose streptozotocin injections, following the model developed by $\mathrm{Wu}$ et al. (2010). In the original report, diabetes was induced in mice starting at 17 months, and these mice demonstrated severe nephropathy associated with elevated markers of oxidative stress, endoplasmic reticular stress, and macrophage-derived inflammation at 22 months ( $\mathrm{Wu}$ et al. 2010). Induction of diabetes in younger mice (4 months old) did not produce kidney lesions after a similar level and duration of hyperglycemia. We modified this model to start the streptozotocin injections in 14-month-old mice and assessed kidney histopathology after 4 months of stable hyperglycemia ( $\sim 18$ months old mice). We chose this younger age to minimize potential confounding effects of age-related cancers that become prominent, especially in WT mice, after 18 months (Conover et al. 2010). In our protocol, mice with visual signs of tumor at harvest would be removed from the study and there would be no further analyses; no animals were removed in this cohort due to tumors. Under this modified model, diabetic WT mice developed several features of nephropathy, i.e. thickening of Bowman's capsule, and mesangial expansion, albeit not to the level of severity seen in the study by $\mathrm{Wu}$ et al. (2010). They also had increased macrophage immunostaining especially around glomeruli. These were significantly reduced in diabetic Papp-A KO mice.
To distinguish diabetes-induced vs age-related nephropathy, we also analyzed kidneys of non-diabetic WT and PAPP-A KO mice. There was no evidence of thickened Bowman's capsule, increased glomerular size, or mesangial expansion. However, tubule dilation and mononuclear cell infiltration occurred to a similar extent. Inflammation and oxidative stress are important contributors to kidney aging. Diabetes accelerates the aging phenotype in the kidney because of the additional hyperglycemia-induced stress (Wu et al. 2010). PAPP-A KO mice show enhanced resistance to inflammatory and oxidative stress (Conover 2010), which may explain, in part, the decrease in agerelated kidney tubule dilation and relative resistance to the development of diabetic nephropathy.

\section{Proposed role of IGF1 and PAPP-A in diabetic nephropathy}

The renal IGF system appears to be a major contributor to the development of diabetic nephropathy (Rabkin \& Schaefer 2004, Vasyleva \& Ferry 2007, Bach 2012). IGF1 is synthesized and secreted by mesangial cells and has been shown to bind specific receptors on glomerular cells (Abrass et al. 1988, Tack et al. 2002). Furthermore, IGF1 synthesis and receptor expression are increased in mesangial cells from diabetic mice (Oemar et al. 1991, Tack et al. 2002) and experimental diabetes increases IGF1 receptor expression in the kidney (Werner et al. 1990). Exposing mesangial cells to IGF1 increases cell proliferation and matrix production while suppressing matrix degradation. Mesangial cell proliferation and matrix accumulation are mediated in part by increased mesangial cell sensitivity to IGF1 in the presence of high glucose (Horney et al. 1998). Thus, IGF1 action increases in diabetic kidney in an autocrine/paracrine manner that promotes matrix production and mesangial cell proliferation. We propose PAPP-A as another regulatory component, enhancing local IGF1 bioavailability. PAPP-A expression has been shown to increase in response to tissue injury (Conover 2012). Moreover, PAPP-A expression is potently stimulated by macrophage-derived proinflammatory cytokines, tumor necrosis factor- $\alpha$, and interleukin $1 \beta$ in fibroblasts and vascular smooth muscle cells and by transforming growth factor- $\beta$ in human osteoblasts (Ortiz et al. 2003, Resch et al. 2004, Conover et al. 2006). These factors are also involved in injury response in kidney. Further in vitro studies are necessary to determine whether there are similar effects on PAPP-A expression and IGF action in mesangial cells.

The studies herein advance our understanding of PAPP-A in the kidney and provide a scientific rationale

Published by Bioscientifica Ltd 
for targeting PAPP-A as a way to inhibit the development and/or progression of kidney pathology in diabetes and aging.

\section{Declaration of interest}

J R M, Z T R, and R J M declared no conflict of interest. G R M is employed by London Metropolitan University and travel/accommodation/meeting expenses unrelated to activities listed covered by British Society of Immunology. J H M obtained a grant from Ansh Labs (Webster, TX, USA), and patents for selective exosite inhibition of PAPP-A activity against IGFBP4. C O obtained a grant from Ansh Labs, Danish Research Council, and patents for selective exosite inhibition of PAPP-A activity against IGFBP4. C A C obtained grants, NIH AG028141 and HL074871, from the Ted Nash Long Life Foundation, and from Ansh Labs; patents for marker for inflammatory conditions (issued), IGF binding protein 4 protease (issued), transgenic mouse lacking PAPP-A activity (issued), and treatment of osteoporosis (issued); and royalties for marker for inflammatory conditions.

\section{Funding}

This work was funded in part by a sponsored research grant from Ansh Labs (to C A C)

\section{Author contribution statement}

J R M designed and performed the mouse experiments, contributed to the draft manuscript, and reviewed and edited the revised versions of the manuscript. Z T R developed and performed PAPP-A immunohistochemistry and reviewed and edited the manuscript. G R M provided Ig expression plasmids and reviewed the manuscript. J H M generated the PAPP-A MAB and reviewed the manuscript. $C O$ generated the PAPP-A MAB and reviewed and edited the manuscript. $R J M$ assessed histopathology and immunohistochemistry and reviewed and edited the manuscript. C A C designed the experiments, analyzed data, prepared tables and figures, drafted the manuscript, and approved the final version of the manuscript.

\section{Acknowledgements}

The authors acknowledge the technical assistance of Laurie Bale, Jacquelyn Grell, Suban Chakraborty, Sally West, and Anthony Croatt, all from the Mayo Clinic (Rochester, Minnesota, USA).

\section{References}

Abrass C, Raugi G, Gabourel L \& Lovet DH 1988 Insulin and insulin-like growth factor I binding to cultured rat glomerular mesangial cells. Endocrinology 123 2432-2439. (doi:10.1210/endo-123-5-2432)

Astrup AS, Tarnow L, Christiansen M, Hansen PR, Parving H-H \& Rossing P 2007 Pregnancy-associated plasma protein A in a large cohort of type 1 diabetic patients with and without diabetic nephropathy: a prospective follow-up study. Diabetic Medicine 12 1381-1385. (doi:10.1111/j.14645491.2007.02283.x)

Bach LA 2012 The insulin-like growth factor system in kidney disease and hypertension. Current Opinion in Nephrology and Hypertension 21 86-91. (doi:10.1097/MNH.0b013e32834dc1a2)

Conover CA 2010 PAPP-A: a new anti-aging target? Aging Cell 9 942-946. (doi:10.1111/j.1474-9726.2010.00630.x)
Conover CA 2012 Key questions and answers about pregnancy-associated plasma protein-A. Trends in Endocrinology and Metabolism 23 242-249. (doi:10.1016/j.tem.2012.02.008)

Conover CA, Bale LK, Overgaard MT, Johnstone EW, Laursen UH, Fuchtbauer E-M, Oxvig C \& van Deursen J 2004 Metalloproteinase pregnancy-associated plasma protein A is a critical growth regulatory factor during fetal development. Development 131 1187-1194. (doi:10.1242/dev.00997)

Conover CA, Bale LK, Harrington SC, Resch ZT, Overgaard MT \& Oxvig C 2006 Cytokine stimulation of pregnancy-associated plasma protein A expression in human coronary artery smooth muscle cells: inhibition by resveratrol. American Journal of Physiology. Cell Physiology 290 C183-C188. (doi:10.1152/ajpcell.00199.2005)

Conover CA, Harrington SC, Bale LK \& Oxvig C 2007 Surface association of pregnancy-associated plasma protein-A accounts for its colocalization with activated macrophages. American Journal of Physiology. Heart and Circulatory Physiology 292 H994-H1000. (doi:10.1152/ajpheart. 00798.2006)

Conover CA, Bale LK, Mader JR, Mason MA, Keenan KP \& Marler RL 2010 Longevity and age-related pathology of mice deficient in pregnancyassociated plasma protein-A. Journals of Gerontology. Series A, Biological Sciences and Medical Sciences 65 590-599. (doi:10.1093/ gerona/glq032)

Fioretto P \& Mauer M 2007 Histopathology of diabetic nephropathy. Seminars in Nephrology 27 195-207. (doi:10.1016/j.semnephrol.2007. 01.012)

Horney MJ, Shirley DW, Kurtz DT \& Rosenzweig SA 1998 Elevated glucose increases mesangial cell sensitivity to insulin-like growth factor I. American Journal of Physiology: Renal Physiology $\mathbf{4 3}$ F1045-F1053.

Hourvitz A, Kuwahara A, Hennebold JD, Tavares AB, Negishi H, Lee TH, Erickson GF \& Adashi EY 2002 The regulated expression of the pregnancy-associated plasma protein-A in the rodent ovary: a proposed role in the development of dominant follicles and of corpora lutea. Endocrinology 143 1833-1844. (doi:10.1210/en.143.5. 1833)

Lawrence JB, Oxvig C, Overgaard MT, Sottrup-Jensen L, Gleich GJ, Hays LG, Yates JR III \& Conover CA 1999 The insulin-like growth factor (IGF)-dependent IGF binding protein-4 protease secreted by human fibroblasts is pregnancy-associated plasma protein-A. PNAS 96 3149-3153. (doi:10.1073/pnas.96.6.3149)

Lin TM, Galbert SP, Kiefer D, Spellacy WN \& Gall S 1974 Characterization of four human pregnancy-associated plasma proteins. American Journal of Obstetrics and Gynecology 118 223-236.

Lupia E, Elliot SJ, Lenz O, Zheng F, Hattori M, Striker GE \& Striker LJ 1999 IGF-1 decreases collagen degradation in diabetic NOD mesangial cells: implications for diabetic nephropathy. Diabetes 48 1638-1644. (doi:10.2337/diabetes.48.8.1638)

Oemar BS, Foellmer HG, Hodgdon-Anandant L \& Rosenzweig SA 1991 Regulation of insulin-like growth factor I receptors in diabetic mesangial cells. Journal of Biological Chemistry 266 2369-2373.

Ortiz CO, Chen B-K, Bale LK, Overgaard MT, Oxvig C \& Conover CA 2003 Transforming growth factor- $\beta$ regulation of the insulin-like growth factor binding protein-4 protease system in cultured human osteoblasts. Journal of Bone and Mineral Research 18 1066-1072. (doi:10.1359/ jbmr.2003.18.6.1066)

Qin X, Wergedal JE, Rehage M, Tran K, Newton J, Lam P, Baylink DJ \& Mohan S 2006 Pregnancy-associated plasma protein-A increases osteoblast proliferation in vitro and bone formation in vivo. Endocrinology 147 5653-5661. (doi:10.1210/en.2006-1055)

Rabkin R \& Schaefer F 2004 New concepts: growth hormone, insulin-like growth factor-I and the kidney. Growth Hormone \& IGF Research $\mathbf{1 4}$ 270-276. (doi:10.1016/j.ghir.2004.02.001)

Resch ZT, Chen B-K, Bale LK, Oxvig C, Overgaard MT \& Conover CA 2004 Pregnancy-associated plasma protein A gene expression as a target of

Published by Bioscientifica Ltd. 
inflammatory cytokines. Endocrinology 145 1124-1129. (doi:10.1210/ en.2003-1313)

Schlondorff DO 2008 Overview of factors contributing to the pathophysiology of progressive renal disease. Kidney International $\mathbf{7 4}$ 860-866. (doi:10.1038/ki.2008.351)

Steffes MW, Osterby R, Chavers B \& Mayer SM 1989 Mesangial expansion as a central mechanism for loss of kidney function in diabetic patients. Diabetes 38 1077-1081. (doi:10.2337/diabetes.38.9.1077)

Swindell WR, Masternak MM \& Bartke A 2010 In vivo analysis of gene expression in long-lived mice lacking the pregnancy-associated plasma protein A (PAPPA) gene. Experimental Gerontology 45 366-374. (doi:10.1016/j.exger.2010.02.009)

Tack I, Elliot SJ, Potier M, Rivera A, Striker GE \& Striker LJ 2002 Autocrine activation of the IGF-I signaling pathway in mesangial cells isolated from diabetic NOD mice. Diabetes 51 182-188. (doi:10.2337/diabetes. 51.1.182)
US Renal Data System: USRDS 2008 Annual Data Report: Atlas of Chronic Kidney Disease and End-Stage Renal Disease in the United States. vol 2, Bethesda, MD, USA: National Institutes of Health, National Institute of Diabetes and Digestive and Kidney Diseases.

Vasyleva TL \& Ferry RJ Jr 2007 Novel roles of the IGF-IGFBP axis in etiopathophysiology of diabetic nephropathy. Diabetes Research and Clinical Practice 76 177-186. (doi:10.1016/j.diabres.2006.09.012)

Werner H, Shen-Orr Z, Stannard B, Burguera B, Roberts CT Jr \& LeRoith D 1990 Experimental diabetes increases insulin-like growth factor I and II receptor concentration and gene expression in kidney. Diabetes 39 1490-1497. (doi:10.2337/diabetes.39.12.1490)

Wu J, Zhang R, Torreggiani M, Ting A, Xiong H, Striker GE, Vlassara H \& Zheng F 2010 Induction of diabetes in Aged C57B6 mice results in severe nephropathy: an association with oxidative stress, endoplasmic regiculum stress, and inflammation. American Journal of Pathology 176 2163-2176. (doi:10.2353/ajpath.2010.090386)

Received in final form 15 July 2013

Accepted 23 July 2013

Accepted Preprint published online 23 July 2013 http://joe.endocrinology-journals.org DOI: 10.1530/JOE-13-0167
C 2013 Society for Endocrinology Printed in Great Britain
Published by Bioscientifica Ltd. 